Mr Goran Tadić, potpukovnik, dipl. inž.

VP 2579-1, Beograd

\section{OCENA ORGANIZACIONIH REŠENJA SAOBRAĆAJNE SLUŽBE PRIMENOM METODE OCENA KOMPONENTI ORGANIZACIJE}

UDC: $356.257: 005.74$

Rezime:

Za ocenu postojećih organizacionih rešenja u naučnoj organizaciji rada postoji više metoda. Koja će od njih biti primenjena zavisi od toga koji se deo organizacione strukture ocenjuje. Na primeru ocene organizovanosti statičnog dela organizacione strukture Saobraćajne službe korpusa Kopnene vojske, u radu je prikazana primena metode ocene komponenti organizacije. Kompletna metodologija analize prikazana je na organizaciji Saobraćajne službe u korpusnoj operaciji.

Ključne reči: organizacija, organizaciona struktura, organizovanost, analiza, komponente.

\title{
EVALUATION OF ORGANIZATIONAL SOLUTIONS IN TRANSPORT AND COMMUNICATION SERVICE USING THE METHOD OF ASSESSING ORGANIZATION COMPONENTS
}

Summary:

There are several methods to assess existing organizational solutions within a scientific work organization. Which one is to be applied depends on what part of the organizational structure is assessed. This study gives the methods employed for assessment of organizational elements based on the assessment of the organization level of the organization structure of transport and communication service for Land forces corps. The complete methodology of this study is shown on the example of organization of transport and communication service within corps operations.

Key words: organization, organizational structure, organizational validity, analysis, components.

\section{Uvod}

Ocena organizovanosti postojećih organizacionih rešenja Saobraćajne službe (SbSl) može se izvršiti preko: meto$\mathrm{da}$ analize $\mathrm{u}$ organizacionim teorijama društva, organizacionih analiza u vojsci i izborom primerenih metoda.

Analizu stanja organizacionih struktura u društvu autori razmatraju kao jednu značajnu fazu za projektovanje organizacija. Najveći broj autora pod analizom podrazumeva analizu zadatka i shvata je kao osnovni element izgradnje organizacione strukture, zatim metode za ocenu postojećih organizacionih rešenja, kao i analizu informacija i komunikacija.

Analizom stanja želi se stvoriti slika o postojećem načinu organizovanja organizacije, kako bi se na osnovu toga uklonili uočeni nedostaci. $\mathrm{Za}$ to su razvijene mnoge metode, a posebno metode za analizu zadataka $\mathrm{i}$ analizu informacija $\mathrm{i}$ komunikacija. Kompleksna analitička metoda i metoda procesnih funkcija predstavljaju doprinos analizi zadataka, a istovremeno to su metode kritičkog ocenjivanja postojećih organizacijskih reše- 
nja. Pored ovih metoda za ocenu organizacionih rešenja koriste se i metoda određivanja organizovanosti preko komponenti i metoda određivanja dobrote organizovanosti.

$\mathrm{Za}$ analizu stanja organizacionih struktura u vojsci postoji prilaz u kojem je ona bitan uslov za izgradnju organizacione strukture, odnosno za njeno funkcionisanje.

Sagledavanjem karakteristika, i polazeći od iskustava metoda za analizu stanja u društvu i vojsci može se odabrati odgovarajuća metodologija za ocenu postojećih organizacijskih rešenja Saobraćajne službe. Takođe, mogu se odrediti zahtevi za izmene i poboljšanja u funkcionisanju organizacione strukture $\mathrm{SbSl}$, nakon izvršene analize.

Sve navedene metode za ocenu postojećih organizacionih rešenja mogu se, uz određene modifikacije i prilagođavanja, primeniti i za analizu organizacione strukture Saobraćajne službe. U radu je prikazana primena metode određivanja organizovanosti preko komponenata, koja polazi od organizacije kao sistema, za ocenu organizacijske valjanosti organizacione strukture Saobraćajne službe korpusa Kopnene vojske u napadnoj operaciji. Napadna operacija je najviši i najsloženiji oblik organizovanja i izvođenja napadnih dejstava, pa je kao takva obrađena u radu.

\section{Primena metode određivanja organizovanosti preko komponenata}

Osim kompleksne analitičke metode procesnih funkcija kod nas je razvijena i metoda određivanja organizovanosti oce- njivanjem promena na komponentama. $\mathrm{U}$ koncipiranju ove analitičke metode [1] polazi se od organizacije kao sistema u kojem treba tako uskladiti sredstva za proizvodnju sa naprezanjima pri radu da se ostvari proizvodnja uz najmanje trošenje sredstava i minimalna naprezanja. Razvijajući tu svoju ideju autor utvrđuje komponente koje su prema njegovom mišljenju uslov organizovanja svake organizacije bez obzira na njenu veličinu.

Posmatrajući proizvodnju kao organizaciju mogu se izdvojiti sledeće komponente koje su uslov njenog organizovanja:

- kadrovi,

- predmet rada,

- sredstva rada,

- radni uslovi,

- metode rada,

- potrošač,

- novac.

Svaka od navedenih komponenti menja se tokom funkcionisanja organizacije pod uticajem sledećih organizacijskih postupaka: pribavljanja, korišćenja, održavanja i obnavljanja.

Prvi postupak označava zadatke osiguravanja, odnosno snabdevanja organizacije komponentama koje se u drugom postupku uključuju u proizvodni proces prema njihovim karakterističnim svojstvima. Pod postupkom održavanja podrazumevaju se zadaci kojima se sprečava opadanje karakterističnih proizvodnih svojstava komponenti ispod nužno potrebnog minimuma, dok se obnavljanje odnosi na reprodukciju značajnih svojstava ili na zamenu starih komponenata novima. Ako je organizacija dobro organizovana, svaka komponenta će proći kroz sve te postupke. To kod kadrova, na primer, znači: 
- oglašavanje potrebe za radnom snagom, izbor radnika i probni rad,

- korišćenje sposobnosti radnika,

- higijensko-tehnička i zdravstvena zaštita radnika,

- permanentno obrazovanje radnika i plansko pripremanje zamene.

Da bi se utvrdilo kako se, u stvari, menjaju komponente $u$ određenoj organizaciji, potrebno je odrediti i oceniti valjanost svakog postupka prema tome koliko on udovoljava uslovima pripreme, planiranja i kontrole. Razrađeni su kriterijumi za ocenjivanje i detaljno uputstvo za određivanje ocena. Svaka organizacijska komponenta ocenjuje se preko kriterijuma, ocenama od 0 do 3 , i to za svaki postupak. Ocene moraju biti detaljno obrazložene i dokazane iscrpnom analizom, $\mathrm{u}$ protivnom nemaju vrednosti (tabela 1, [2]).

Kriterijumi za ocenjivanje promena na komponentama organizacije

\begin{tabular}{|l|c|}
\hline \multicolumn{1}{|c|}{ Kriterijumi za ocenjivanje } & Ocene \\
\hline Stihijsko provođenje postupka & 0 \\
\hline $\begin{array}{l}\text { Provođenje postupka postoji kao zadatak, } \\
\text { ali se obavlja neredovno i za to nema od- } \\
\text { ređenog zaduženog radnika }\end{array}$ & 1 \\
\hline $\begin{array}{l}\text { Za provođenje postupka postoji zadužen } \\
\text { radnik, ali nema razrađenog sistema pri- } \\
\text { preme i kontrole }\end{array}$ & 2 \\
\hline $\begin{array}{l}\text { Za provođenje postupka postoji organiza- } \\
\text { cijski propis i zadužen radnik, obavljaju se } \\
\text { odgovarajuće pripreme i kontrola }\end{array}$ & 3 \\
\hline
\end{tabular}

Radi jednostavnijeg i preglednijeg rada koristi se odgovarajuća tabela za upis ocena (tabela 2).
Tabela 2

Tabela ocena organizacijskog nivoa

\begin{tabular}{|c|c|c|c|c|c|c|c|c|}
\hline Komponente & 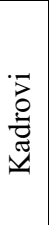 & 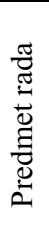 & 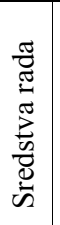 & 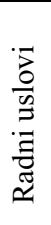 & 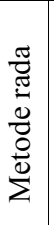 & 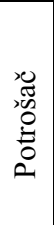 & $\begin{array}{l}0 \\
z \\
z \\
z\end{array}$ & 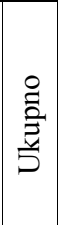 \\
\hline Osiguranje & & & & & & & & \\
\hline Korišćenje & & & & & & & & \\
\hline Održavanje & & & & & & & & \\
\hline Obnavljanje & & & & & & & & \\
\hline UKUPNO & & & & & & & & \\
\hline
\end{tabular}

Za provođenje svakog postupka na svakoj komponenti formuliše se organizacijska regulativa i određuju istraživači, a postupak se priprema i kontroliše. Pri tome se svakoj komponenti dodeljuju po četiri najviše ocene, pa njihov ukupni zbir iznosi 84 boda. Organizovanost se utvrđuje prema vrednostima iz sledeće skale [2]:

- 1-34 slaba organizovanost,

- 35-59 dobra organizovanost,

- 60-74 vrlo dobra organizovanost,

- 75-84 odlična organizovanost.

Utvrđivanje organizovanosti ovom metodom je jednostavno, ali je dobijena slika vrlo gruba.

\section{Ocena stanja osnovnih komponenti organizacione strukture Saobraćajne službe korpusa}

Pri izboru metoda za analizu stanja i uticaja organizacione strukture Saobraćajne službe na saobraćajnu podršku 
(SbP) korpusa u napadu, osnovni kriterijum predstavlja definisanje pojma „organizacione strukture“.

Većina istraživača u teoriji organizacije kao poseban elemenat (komponentu, dimenziju) organizacije izdvaja njenu strukturu. Pojam organizacione strukture, kao i organizacije od različitih autora različito je definisan. Međutim, za većinu struktura određen je broj elemenata neke celine i njihovih međusobnih veza, što se uspostavlja koncepcijom povezivanja strukture. U tome je bitno istaći da svaki elemenat ima uticaj na funkcionisanje celine, a celina opredeljuje ulogu, mesto i ponašanje elemenata. Organizaciona struktura predstavlja složenu tvorevinu koja se stvara i oblikuje radi ostvarivanja postavljenih ciljeva organizacije, i koja nužno uključuje kako činioce rada tako i njihove međusobne odnose. Strukturu uvek čini određen kompaktan sistem rasporeda raspoloživih ljudskih i materijalnih resursa organizacije, zajedno sa njihovim međusobnim odnosima i vezama. Kao takva ona se javlja i deluje u svakoj organizaciji, bez obzira na njenu veličinu i vrstu, a njena osnovna karakteristika je statičnost. U vojsci se za organizacionu strukturu koristi termin formacija ili organizacijsko-formacijsko rešenje koje čine ljudi i materijalno-tehnička sredstva, odnosi i veze među njima.

Pri analizi stanja i uticaja organizacione strukture saobraćajne službe na saobraćajnu podršku korpusa u napadnoj operaciji, na osnovu prethodno iznetog, može se zaključiti da je čini:

- organizacijsko-formacijsko rešenje (statični deo strukture, upravni i izvršni organi $\mathrm{SbSl}$ ),

- funkcije i zadaci koje izvršava (dinamički deo, odnosno saobraćajna podrška).
Za sagledavanje stanja statičnog dela strukture najpogodnija je metoda ocene komponenti, a dinamičkog dela - metoda procesnih funkcija.

$\mathrm{Za}$ primenu izabranih metoda za ocenu stanja organizacione strukture $\mathrm{SbSl}$ i njihovog uticaja na funkcionisanje saobraćajne podrške korpusa u napadnoj operaciji, neophodno je izvršiti odgovarajuća prilagođavanja specifičnostima vojne saobraćajno-transportne organizacije i uslovima napadne operacije korpusa. Pri prilagođavanju specifičnostima organa SbSl korpusa i SbP korpusa u napadnoj operaciji koriste se elementi metoda analize u vojsci (analiza činioca organizacione strukture, analiza integracije funkcija, analiza zadataka organizacione strukture, analiza veza i odnosa u organizacionoj strukturi, analiza pojava koje uzrokuju neefikasnost u radu organizacione strukture).

Saobraćajno-transportni sistem u vojsci je vrlo složen, što proizilazi iz povezanosti šest grupa organizacionih struktura u društvu i vojsci i dve osnovne funkcije (slika).

Zbog složenosti strukture saobraćajno-transportne organizacije u vojsci i kompleksnosti priprema i odvijanja napadne operacije, za ocenu njene valjanosti potrebno je koristiti i anketnu metodu, kao pomoćnu, radi prikupljanja podataka za primenu metode ocene komponenti.

\section{Prilagođavanje metode uslovima korpusne operacije}

Da bi se metoda ocene komponenti mogla upotrebljavati neophodno je:

- izvršiti izbor osnovnih komponenti, 


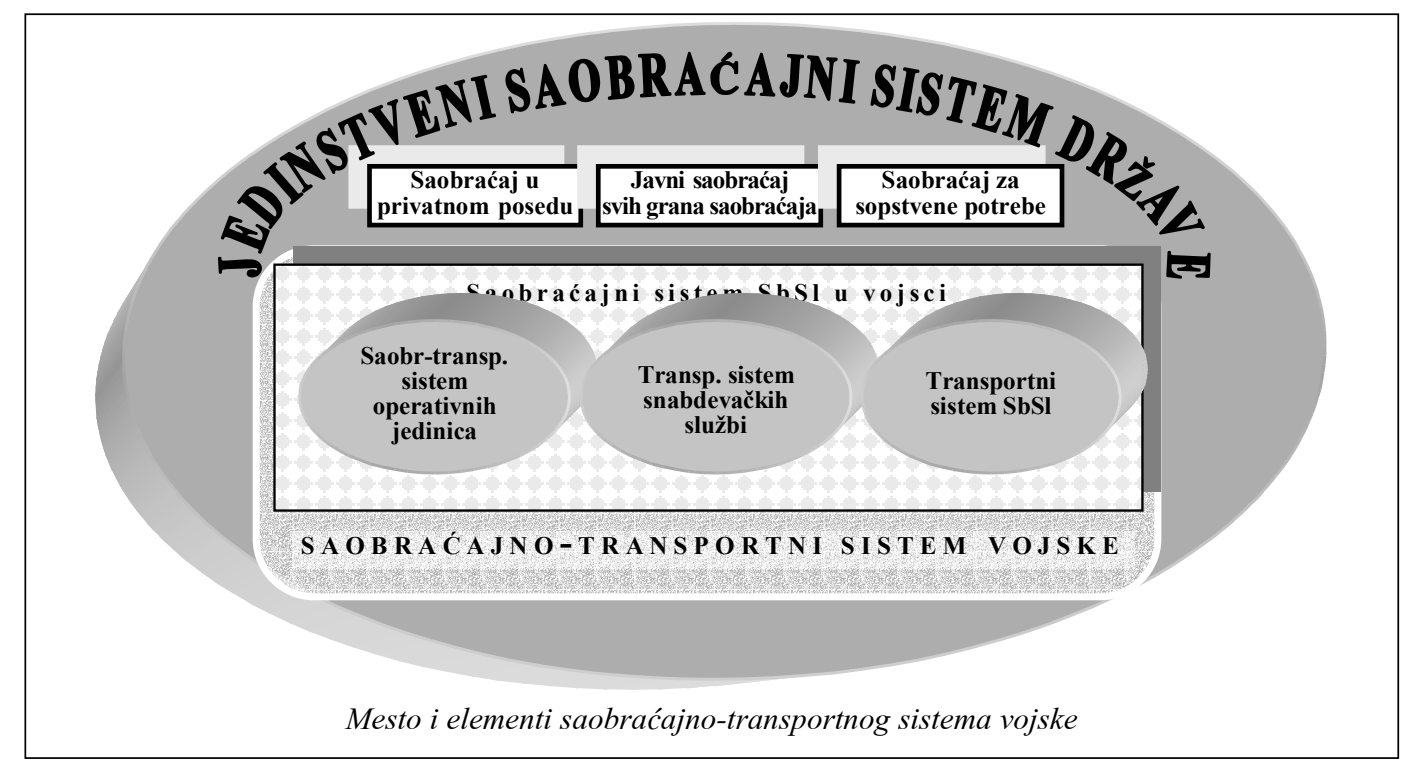

- odrediti postupke organa SbSl specifične za korpus u napadnoj operaciji,

- definisati kriterijume za ocenu postupaka u odnosu na odabrane komponente i njihove promene.

Analizom osnovnih komponenti organizacije SbSl za korpus u napadnoj operaciji, polazeći od postavki [1], mogu se izdvojiti:

- upravni organi SbSl u komandama, starešine SbSl u izvršnim organima i vozači motornih vozila,

- motorna vozila svih kategorija u jedinicama korpusa,

- uslovi za odvijanje operacije korpusa. Zbog visokog stepena neodređenosti uslovi se moraju posebno razmatrati, što nije obuhvaćeno ovim radom.

Ostale komponente za globalni prilaz se ne razmatraju.

Od postupaka vezanih za nadležnost SbSl razmatraju se:

- obezbeđenje komponenti, odnosno popunjenost ljudstvom i motornim vozilima, odnosno preduzimanje potrebnih mera prema uslovima za korpusnu operaciju,
- racionalno korišćenje resursa $\mathrm{SbSl}$,

- zanavljanje komponenti, prema procenama gubitaka u korpusnoj operaciji u napadu.

Deo održavanja, pre svega vozila, u nadležnosti je tehničke službe.

Kriterijumi za ocenjivanje promena kod komponenti organizacije, dobijeni anketom za korpusnu operaciju, prikazani su u tabeli 3 .

Tabela 3

Kriterijumi ocene postupaka pri promeni stanja komponenti organizacije SbSl za korpus u napadnoj operaciji

\begin{tabular}{|l|c|c|}
\hline \multirow{2}{*}{ Kriterijumi za ocenjivanje } & \multicolumn{2}{|c|}{ Ocene } \\
\cline { 2 - 3 } & $\begin{array}{c}\text { Prema } \\
\text { organiz. } \\
\text { rada }\end{array}$ & $\begin{array}{c}\text { Za } \\
\text { korpusnu } \\
\text { operaciju }\end{array}$ \\
\hline Stihijsko provođenje postupka & 0 & 0 \\
\hline $\begin{array}{l}\text { Provođenje postupka postoji kao za- } \\
\text { datak, ali se obavlja neredovno i ne- } \\
\text { ma za to određenog zaduženog lica }\end{array}$ & 1 & 1 \\
\hline $\begin{array}{l}\text { Za provođenje postupka postoji za- } \\
\text { duženo lice, ali nema razrađenog } \\
\text { sistema pripreme i kontrole }\end{array}$ & 2 & 2 \\
\hline $\begin{array}{l}\text { Za provođenje postupka postoji or- } \\
\text { ganizacijski propis i zaduženo lice, } \\
\text { obavljaju se odgovarajuće pripreme } \\
\text { i kontrola }\end{array}$ & 3 & 3 \\
\hline
\end{tabular}


Ocene u tabeli 3 date su u teoriji naučne organizacije rada i dobijene anketom.

Prosečne ocene stanja komponenti dobijene anketom prikazane su u tabeli 4. Organizacija ankete, izbor eksperata i ocena pouzdanosti rezultata obavlja se na osnovu nekih od prilaza iz naučne literature.

Vrednosti prosečnih ocena stanja izabranih komponenti organizacione strukture dobijene su preko izraza:

$\bar{O}=\frac{\sum_{1}^{n} O_{i}}{n}$

gde je:

$n=1 \ldots 30$, broj eksperata (u anketi je učestvovalo 30 eksperata),

$i=1 \ldots 18$, broj ocena po komponentama.

Vrednosti prosečnih ocena stanja komponenti organizacione strukture Saobraćajne službe, kao i kriterijumi ocene postupaka pri promeni stanja komponenti za korpus u napadnoj operaciji, prikazani u tabelama $3 \mathrm{i}$ 4, dobijeni su istraživanjem [3].

\section{Analiza rezultata}

Prosečne ocene stanja komponenti u tabeli 4 dobijene su korišćenjem date formule za obradu rezultata ankete. Svaka organizacijska komponenta (ima ih 6), ocenjuje se preko kriterijuma, za svaki postupak (ima ih 3 ), ocenama od 0 do 3 . Ukupno se daje $18(6 \times 3)$ ocena sa maksimalnom vrednošću 3 , a maksimalni broj bodova je $54(18 \times 3)$.

Organizovanost se utvrđuje prema vrednostima iz sledeće skale:

- 1-22 slaba organizovanost,

-23-39 dobra organizovanost,

- 40-49 vrlo dobra organizovanost,

-50-54 odlična organizovanost.
Tabela 4

Prosečne ocene stanja komponenti organizacije

SbSl za korpus u napadnoj operaciji

a) priprema operacije

\begin{tabular}{|c|c|c|c|c|c|c|c|}
\hline Komponente & $\begin{array}{r}\mathrm{Ra} \\
(\mathrm{lju}\end{array}$ & $\begin{array}{l}\text { dna snas } \\
\text { lstvo } \mathrm{Sb}\end{array}$ & & & $\begin{array}{l}\text { Iotor } \\
\text { yozil }\end{array}$ & & \\
\hline Postupci & 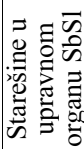 & 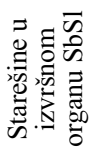 & 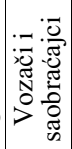 & 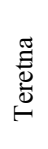 & 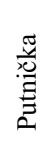 & $\begin{array}{l}: \overline{7} \\
\overline{0} \\
\frac{0}{2} \\
\dot{0}\end{array}$ & $\begin{array}{l}\hat{5} \\
\tilde{5}\end{array}$ \\
\hline $\begin{array}{l}\text { Obezbeđenje } \\
\text { komponenti }\end{array}$ & 3 & 3 & 2 & 3 & 2 & 2 & 15 \\
\hline $\begin{array}{l}\text { Racionalno } \\
\text { korišćenje }\end{array}$ & 2 & 2 & 2 & 2 & 2 & 1 & 11 \\
\hline Zanavljanje & 3 & 3 & 3 & 3 & 3 & 3 & 18 \\
\hline UKUPNO & 8 & 8 & 7 & 8 & 7 & 6 & 44 \\
\hline
\end{tabular}

b) Izvođenje operacije

\begin{tabular}{|c|c|c|c|c|c|c|c|}
\hline \multirow[b]{2}{*}{ Postupci } & \multicolumn{3}{|c|}{$\begin{array}{l}\text { Radna snaga } \\
\text { (ljudstvo SbSl) }\end{array}$} & \multicolumn{3}{|c|}{$\begin{array}{l}\text { Motorna } \\
\text { vozila }\end{array}$} & \multirow[b]{2}{*}{$\begin{array}{l}0 \\
Z \\
\vdots \\
\vdots \\
\vdots\end{array}$} \\
\hline & 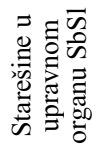 & 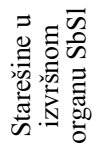 & 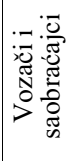 & 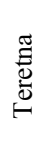 & 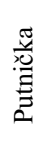 & $\begin{array}{l}:=\bar{y} \\
\frac{0}{0} \\
\frac{0}{2}\end{array}$ & \\
\hline $\begin{array}{l}\text { Obezbeđenje } \\
\text { komponenti }\end{array}$ & 2 & 2 & 2 & 2 & 2 & 1 & 11 \\
\hline $\begin{array}{l}\text { Racionalno } \\
\text { korišćenje }\end{array}$ & 2 & 2 & 2 & 2 & 2 & 0 & 10 \\
\hline Zanavljanje & 3 & 3 & 3 & 3 & 3 & 3 & 18 \\
\hline UKUPNO & 7 & 7 & 7 & 7 & 7 & 4 & 39 \\
\hline
\end{tabular}

Skala je dobijena analogno navedenoj skali za ocenu organizovanosti. Posmatrajući prikazane rezultate u tabelama, uočava se da je u izvođenju operacije organizovanost SbSl dobra (39 bodova) što, u odnosu na skalu, predstavlja minimum prihvatljivosti organizovanosti. U pripremi operacije organizovanost je vrlo dobra (44 boda), mada je broj bodova dosta nizak. 
Analizirajući ocene komponenti po postupcima uočava se da najviše ocene ima postupak zanavljanja kod svih komponenti. Imajući u vidu da u vojnoj organizaciji postoji propisana procedura, kao i to da postoje lica zadužena za obezbeđenje i zanavljanje ljudstva i sredstava, može se smatrati da su te ocene sasvim realne.

Najniže ocene dobijene su za postupak racionalnog korišćenja i obezbeđenja, i to posebno komponente koja se odnosi na motocikle, što ukazuje na to da u organizacijskoj celini u kojoj se nalaze motocikli nešto nije u redu sa njihovom upotrebom. Može se zaključiti da organizacijske celine u kojima se nalaze motocikli u kombinaciji sa ostalim komponentama, a to su jedinice saobraćajne vojne policije (SbVP), nemaju dobro regulisan način upotrebe, dok problemi obezbeđenja postoje van institucija korpusa. Pošto u korpusu postoji četa SbVP zaključuje se da se ona ne koristi racionalno, odnosno koristi se nenamenski. Pošto je četa SbVP namenjena, pre svega, za regulisanje $\mathrm{i}$ kontrolu saobraćaja i saobraćajno izviđanje, to znači da se ova jedinica ne koristi za izvršenje namenskih zadataka. Posledica toga je neadekvatno obavljanje saobraćajno-operativne funkcije SbP. Za korpus u napadu, gde su prisutna masovna kretanja jedinica, to znači nemogućnost adekvatnog izvršenja kretanja putem izbora komunikacija, regulisanja saobraćaja, odnosno obezbeđenja planiranih kretanja.

Rezultati pokazuju da bi se organizacijska valjanost mogla poboljšati bez ikakvih organizacijskih promena, dakle odmah, obezbeđenjem komponenti, odnosno povećanjem popunjenosti. Za povećanje racionalnosti korišćenja komponenti potrebno je usavršavanje organizacije SbSl i SbP kroz dogradnju i organizacijsko projektovanje.

Dobijeni rezultati su globalni za opštu ocenu organizovanosti, što je i odlika ove metode, tako da se detaljnije analize rade metodama struke, prema potrebi, za komponente čije stanje ne zadovoljava, a može negativno da utiče na odvijanje korpusne operacije.

\section{Zaključak}

Metoda ocene komponenti organizacije pogodna je za utvrđivanje organizovanosti statičkog dela organizacione strukture. Analitički postupak, koji daje metoda ocene komponenti, omogućuje kvantitativno ocenjivanje organizacijskog nivoa, a polazeći od toga i preduzimanje mera za dalje organizacijsko delovanje.

Korišćenjem dobijenih rezultata i odgovarajuće skale vrši se analiza rezultata, na osnovu koje se donose određeni zaključci, kojima se obuhvataju:

- organizovanost za celokupnu organizaciju (njen statički deo),

- ocene komponenti po postupcima (najviše i najniže) i celokupne ocene za komponente pojedinačno,

- ocene postupaka po komponentama (najviše i najniže) i celokupne ocene za postupke pojedinačno,

- mogućnost poboljšanja organizovanosti bez organizacijskih promena,

- mogućnost poboljšanja organizovanosti kroz dogradnju i organizacijsko projektovanje. 
Primena metode ocene stanja osnovnih komponenti organizacione strukture je pogodna i jednostavna. Dobijeni rezultati su globalni za opštu ocenu organizovanosti, što je i odlika ove metode. Detaljnije analize rade se metodama struke prema potrebi.

\section{Literatura:}

[1] Marjanović, S.: Principi i instrukcije za rešavanje organizacionih problema (Knjiga prva - opšti problemi), Privredapublik, Beograd, 1987.

[2] Miladinović, V.: Organizacija rada u saobraćaju i transportu, skripta, CVŠ VJ, Beograd, 1998.

[3] Tadić, G.: Uticaj organizacione strukture saobraćajne službe na funkcionisanje saobraćajnog obezbeđenja korpusa kopnene vojske u napadu, magistarski rad, VA VJ, Beograd, 2000. 